\title{
Phytosanitary effect of the plants - producers of sweet glycosides
}

Svistova I.D., Kuvshinova N.M.

Voronezh state pedagogical University, Voronezh, Russia

E-mail: i.svistova@mail.ru

Key message. In the root zone of plants that accumulate sweet glycosides (honey stevia and naked licorice), a sharp decrease in the phytopathogenic potential of the soil was revealed without increasing its phytotoxic activity.

Keywords: phytopathogens, rhizosphere, plants-producers of sweet glycosides

In the rhizosphere of plants, soil properties change, a specific microbiome is formed, the accumulation of phytopathogens and the growth of phytotoxic activity of the soil is possible. To obtain non-metabolized sweet glycosides, non-traditional sugar plants are introduced into the culture. We have previously studied the structure of the saprotrophic microbial community in the root zone of this group of plants [1].

The aim of this work is to study the effect of monoculture of plants producing sweet glycosides (honey stevia, naked licorice) on the infectious potential and development of soil phytotoxicosis. Soil samples were taken in the dynamics of the season under 4-year monocultures of medicinal plants, control-virgin soil. The phytotoxic activity of the soil was evaluated using biotests on soil plates. The species composition, spatial and temporal frequency of occurrence of phytopathogenic species of micromycetes were determined.

The complex of phytopathogens in the control included 9 types of micromycetes, such as pathogens of root rot and leaf-stem diseases. It was found that Botrytis cinerea, Fusarium solani, F. oxysporum, Alternaria alternata, Stemphyllium botryosum, Cladosporium herbarum, Rhizoctonia solani, Aureobasidium pullulans, Drechslera sorokiniana were not isolated from the soil under the sugar-bearing plants already in the middle of the growing season. In our opinion, the phytosanitary effect of in vivo rhizodeposites of these plants is associated with a decrease in all types of soil acidity (current, exchange, hydrolytic) [2], as well as with the fungicidal effect of their components.

At the same time, the phytotoxic activity of the soil in the root zone of both honey stevia and naked licorice contain 5-12\% inhibition of root growth, which did not exceed the control level and the value regulated by state standard.

Thus, growing honey stevia and licorice naked in a 4-year-old monoculture not only does not cause the development of soil fatigue, but these plants can be recommended for recovery of acidified leached chernozems.

\section{Фитосанитарный эффект растений-продуцентов сладких гликозидов \\ Свистова И.Д., Кувиинова Н.М.}

Воронежский государственный педагогический университет, Воронеж, Россия

\begin{abstract}
Аннотация. В прикорневой зоне растений, накапливающих сладкие гликозиды (стевия медовая и солодка голая), выявлено резкое снижение фитопатогенного потенциала почвы без роста ее фитотоксической активности.
\end{abstract}

Ключевыеслова: фитопатогень, ризосфера, растения-продуценты сладких гликозидов

В ризосфере растений меняются свойства почвы, формируется специфический микробиом, возможно накопление фитопатогенов и рост фитотоксической активности почвы. Для получения неметаболизируемых сладких гликозидов вводят в культуру нетрадиционные растения-сахароносы. Ранее нами изучена структура сапротрофного микробного сообщества в прикорневой зоне этой группы растений [1].

Цель работы - изучение влияния монокультуры растений-продуцентов сладких гликозидов (стевия медовая, солодка голая) на инфекционный потенциал и развитие фитотоксикоза почвы. Пробы почвы отбирали в динамике по сезону под 4-х летними монокультурами лекарственных растений, контроль - целина. Фитотоксическую активность почвы оценивали методом биотестов на почвенных пластинках. Определяли видовой состав, пространственную и временную частоты встречаемости фитопатогенных видов микромицетов.

В состав комплекса фитопатогенов в контроле входили 9 видов микромицетов, в том числе возбудители корневых гнилей и листостебельных болезней. Обнаружено, что из почвы под растениями-подсластителями уже в середине вегетации не выделялись Botrytis cinerea, Fusarium solani, F. oxysporum, Alternaria alternata, Stemphyllium botryosum, Cladosporium herbarum, Rhizoctonia solani, Aureobasidium pullulans, Drechslera sorokiniana. По нашему мнению, фитосанитарный эффект ризодепозитов указанных растений связан со снижением всех видов почвенной кислотности (актуальной, обменной, гидролитической) [2], а также с фунгицидным действием их компонентов.

При этом фитотоксическая активность почвы в прикорневой зоне как стевии медовой, так и солодки голой составляла 5-12\% ингибирования роста корня, что не превышало контрольного уровня и регламентированного ГОСТом значения.

Таким образом, выращивание стевии медовой и солодки голой в 4-летней монокультуре не только не вызывает развития почвоутомления, но данные растения могут быть рекомендованы для оздоровления подкисленных выщелоченных черноземов.

1. Свистова И.Д., Кувшинова Н.М., Назаренко Н.Н. Микробно-растительные ассоциации нетрадиционных сахароносов и продуцентов натуральных подсластителей // Теоретическая и прикладная экология. 2016. №3. С. 41

2. Свистова И.Д., Стекольников К.Е., Кувшинова Н.М. // Почвоведение. 2016. №2. С.214. 